\title{
Varicella-Infected Acquired Immunodeficiency Syndrome Patient with Secondary Infection
}

\author{
Fachrur Razi, Musofa Rusli, Muhammad Vitanata Arfijanto, Bramantono, Usman Hadi and Erwin \\ Astha Triyono \\ Division of Tropical Medicine, Department of Internal Medicine, Faculty of Medicine, Universitas Airlangga, Dr. Soetomo \\ General Hospital, Jl. Prof dr. Moestopo 47 Surabaya 60132, Indonesia \\ apji@fk.unair.ac.id
}

Keywords: Acquired Immunodeficiency Syndrome, Antiretroviral, Human Immunodeficiency Virus, Secondary Infection, Varicella-Zooster Virus.

\begin{abstract}
Human immunodeficiency virus and acquired immunodeficiency syndrome infections are major problems in Indonesia, and antiretroviral therapy can reduce morbidity and mortality. The incidence of VaricellaZoster Virus infection increases with worsening immune function; therefore, early diagnosis, proper management, and early detection of Human immunodeficiency virus infection may inhibit acquired immunodeficiency syndrome progression. A woman aged 27 was admitted to the out-patient unit with blistered skin from one week before hospitalization. She was in a weak condition, and the skin appeared to have pus-filled bullae, partially crusted and visibly eroded with pus. She had a moderate fever, which worsened for one week to $39^{\circ} \mathrm{C}$. She suffered from painful urination and bowel movements in the last one week when exposed to skin lesions around the genitals. She was diagnosed with Human immunodeficiency virus because of weight loss, chronic diarrhea, sprue, oris candidiasis, two-month fever, positive Human immunodeficiency virus rapid test; positive 3-method test and Cluster of Differentiation 4 cell count $17 \%$. The Tzanck test showed the patient was positive with giant cells. Varicella diagnosis was clinically established, but positive Tzanck test, viral or Polymerase Chain Reaction cultures were not performed due to limited cost. According to the results of physical examination and laboratory examination, the patient was diagnosed with varicella with the complication of a secondary infection. Her condition improved during the treatment. Her prognosis improved, but she might later have herpes zoster risk.
\end{abstract}

\section{INTRODUCTION}

Skin is an organ of the human body that plays an important role in the defense of the immune system. This is related to immunocompromised patients; therefore, dermatological manifestations of Human Immunodeficiency Virus (HIV) and Acquired Immunodeficiency Syndrome (AIDS) have become global health problems (Kouznetsov et al., 2009). HIV infection results in dermatological complications as part of opportunistic infection, including HIV staging category (Cook GC, 2009). Varicella-Zoster Virus (VZV) infection, recurrent herpes simplex virus (HSV), oral ulcers, and hairy leukoplakia are commonly reported in the early stages.

Dermatological prevalence of HIV is estimated to be around 90\% worldwide (Sterling TR, 2005; Fauci AS, 2005; Wiwanitkit, 2004). This manifestation is a result of drug reaction, immune reconstitution inflammatory syndrome, or decreased Cluster of Differentiation 4 (CD4) count. Dermatological disorder diagnosis in HIV is difficult because it is atypical with varied pathology, etiology and morphology of lesions (Jordaan, 2008).

Mucocutaneous lesions may be morbiliform with eruption, erythrodermic, umbilicated papules, folliculocentric papules, blistering disease, or ulcers (Cook GC, 2009; Fauci AS, 2005). The main causes of dermatological disorders in HIV/AIDS include infection, inflammation and malignancy. On the other hand, the most common infections found are viral infections (HSV, VZV) and fungi (Zijlstra, 2014). VZV can cause a highly infectious primary infection (chickenpox) and herpes zoster. VZV infection in HIV has a higher risk of secondary infection with significant morbidity and mortality than in non-HIV (Fauci AS, 2005). Varicella- 
infected HIV patients have a risk of recurrent VZV infection 17 times greater than non-HIV patients (Jordaan, 2008).

HIV and AIDS infections have become a national problem (Indonesia), and antiretroviral therapy (ARV) can reduce morbidity and mortality (Lahoti et al., 2017; Nasronudin, 2015). The incidence of VZV infection increases with worsening immune function; therefore, early diagnosis, proper management, and early detection of HIV infection may inhibit progression to AIDS (Jordaan, 2008).

This study discusses an HIV/AIDS patient who had a varicella infection with complications of secondary infection in the skin.

\section{CASE PRESENTATION}

A married woman, Mrs. W, aged 27, housewife, consulted the Skin and Venereal Unit. The patient visited the Outpatient Unit with blistered skin since 1 week pre-hospitalization. She initially had a red rash on the body three days before, before spreading to the hands, left thigh, genitals, buttocks and legs. The rash then became red bumps, filled with fluid which then cracked and left crusting/traces. The liquid was initially clear, before turning to turbid yellow (pus). The red bumps easily cracked when touched or rubbed against clothing, and were very painful. The patient had a moderate fever complaint in the last 4 weeks before visiting the hospital, and it got worse for 1 week to $39^{\circ} \mathrm{C}$. She had painful urination and bowel movements in the last 1 week when exposed to skin lesions around the genitals.

The patient often had oral thrush complaints, white spots in the oral cavity and tongue, hair loss, recurrent diarrhea within two months with fluid feces, dregs, no mucus or blood (currently had no diarrhea) and often experienced vaginal discharge. The patient had reduced appetite, weight loss (10 kg in the last two months), and looser clothes. There were no complaints of hemoptysis, night sweats, chest pain, nausea, vomiting, abdominal pain or hand or foot numbness.

One month earlier, the patient went to a GP with similar complaints and received gentamicin ointment. She had a miscarriage 1 year before. She had married twice, divorced her first husband in 2012 and had 1 child (4 years old). She married again in 2012 and had 1 child (2 years old). The second husband works as a security guard and has a habit of casual sex with multiple partners. He has a previous history of chickenpox, diabetes, hypertension and negative stroke diagnosis. He has a historical use of drugs, alcohol, tattoos, casual sex and no drug injections. The patient had neither a family medical history nor husband's illness history.

The patient's general condition was weak, was in pain (patient cried) with VAS 8-9 and toxic, was compos mentis with a Glasgow Coma Scale (GCS) of 456 , blood pressure of $110 / 80 \mathrm{mmHg}$; heart beats 100 times per minute, regular, and had enough content; respiration rate 24 times per minute; and axillary temperature of $36.7^{\circ} \mathrm{C}$. Height $160 \mathrm{~cm}$, weight $43 \mathrm{~kg}$, BMI $16.79 \mathrm{~kg} / \mathrm{m}^{2}$. No neurological deficits were found. Head and neck examinations found dry mouth mucosa, white spots on the left and right tongue, and oral cavity. There was no conjunctival anemia, jaundice, cyanosis or dyspnea. No cavities were found or signs of infection in the nose, ears, throat, or sinus cavities. No lymph node enlargement nor increased Jugular Venous Pressure (JVP) was found. The patient had a symmetrical chest, without chest wall retraction, with symmetrical breathing movements, first and second heart sound without gallops or heart noises, ictus cordis in the Intracostal Space (ICS) V linea mid clavicula sinistra (LMCS). There were vesicular breathing sounds without rhonchi or wheezing, with palpation of normal tactile fremitus. The abdomen looked flat and supple, and had normal turgor, without tenderness. There were normal bowel sounds. Hepar and lien were not enlarged. We found red bumps. In extremity examination, we found no edema, redness, warmth or dry fingertips. In the examination of local status of regio pedis dextra et sinistra, we found a vesicle with multiple hemorrhagic bullae, crusting and erosion. On the other hand, we found vesicles with erosion and crusting in examination of the local status of thoracic, gluteus and upper extremity regions.

A laboratory examination (September 10, 2015), found hemoglobin ( $\mathrm{Hb}) \quad 10.9 \mathrm{gr} / \mathrm{dl} ; 32.2 \%$ hematocrit, 5,700/uL leukocytes; 78\% granulocytes; $7 \%$ lymphocytes, 250,000/uL platelets, $79 \mathrm{mg} / \mathrm{dl}$ random blood glucose; 2.89 albumin; $14 \mathrm{mg} / \mathrm{dl}$ Blood Urea Nitrogen (BUN); $0.67 \mathrm{mg} / \mathrm{dl}$ serum creatinine; $47 \mathrm{U} / \mathrm{L}$ Serum Glutamic Oxaloacetic Transaminase (SGOT); 27 U/L Serum Glutamic Pyruvic Transaminase (SGPT); $131 \mathrm{mmol} / \mathrm{L}$ sodium; $4.35 \mathrm{mmol} / \mathrm{L}$ potassium; $102 \mathrm{mmol} / \mathrm{L}$ chloride; urinalysis: dark yellow urine; $\mathrm{pH} 5.0$; specific gravity 1.022; glucose negative; bilirubin negative; ketone negative; protein 1+; negative nitrite; negative leukocytes; erythrocytes $0-5 / \mathrm{lp}$; leukocytes $0-5 / \mathrm{lp}$; slight epithelium/lp. A radiology examination found a normal heart size and shape (AP position, 
symmetrical), no visible lung abnormalities, and taper sinus phrenicocostalis. We also found sinus rhythm to be 112 times per minute with a normal axis in electrocardiographic examination.

Based on anamnesis results, physical examination and supported investigation, the patient's diagnosis was suspected to be AIDS, Candidiasis oris, hemorrhagic bullae observation ec. suspected during disease dd vasculitis.

Diagnostics planning used Voluntary Counseling and Testing (VCT) and examinations of CD4, HBsAg, anti HCV, IgG CMV and IgG IgM toxoplasma. A high-calorie, high-protein diet was given as much as 2,100 kcal/day; Kalbamin Infusion: Amino fluid 1:1 (14 drops per minute); 2 ampoule of antrain drip in $100 \mathrm{ml}$ of $\mathrm{NaCl} 0.9 \%$ every 8 hours; Cotrimoxazole Forte $1 \times 1$ tablet orally, 5 Nystatin drops every 6 hours orally and urinary catheter insertion. The patient was treated in the intermediate and infectious care unit room with monitoring of clinical and vital signs.

On the second day of hospitalization (September 11, 2015), the patient still had red bump complaints on the legs, buttocks and genitals. She felt pain, particularly when moving. Based on physical examination, the patient's general condition was weak, she was compos mentis, GCS E4M6V5, blood pressure 110/70 mmHg; $\mathrm{N} 88$ times/min; respiratory rate 18 breaths/min; Temperature $36.8^{\circ} \mathrm{C}$. Visual Analog Scale (VAS) 8. The patient's diagnosis was AIDS, candidiasis oris et vaginalis, chronic pain ec multiple hemorrhagic bullae $\mathrm{dd}$ vasculitis $\mathrm{dd}$ syphilis, and hypoalbuminemia. Diagnostic planning used VCT and examinations of CD4, HBsAg, anti $\mathrm{HCV}$, IgG CMV, IgG toxoplasma IgM, culture and sensitivity from blood, urine and bullae. A highcalorie, high-protein diet was given as much as 2,100 kcal/day; Kalbamin Infusion: Amino fluid D5 1:1:1 (21 drops per minute); Intravenous ketorolac injections at a dose of $3 \times 10 \mathrm{mg}$ (intravenous); cotrimoxazole forte $1 \times 1$ tablet orally and 5 nystatin drops 5 orally every 6 hours with monitoring of clinical and vital signs.

On the fifth-sixth day of hospitalization (September $\left.14^{\text {th }}-15^{\text {th }}, 2015\right)$, the patient still had red bump complaints, yet the pain was reduced. The patient's general condition was sufficient, she was compos mentis, Glagsow Coma Scale (GCS) 456, blood pressure 130/75 $\mathrm{mmHg}$; pulse 90 times/min; respiration rate 20 breaths $/ \mathrm{min}$; temperature $37.2^{\circ} \mathrm{C}$ VAS 7. Based on the local status of regio pedis dextra et sinistra, we found vesicles with multiple hemorrhagic bullae, crusting and erosion. We also found vesicles with erosion and crusting in the gluteus region. From the laboratory test, the serology test for syphilis (STS) was negative, and VCT was positive. The patient's diagnosis was AIDS, candidiasis oris et vaginalis, chronic pain ec multiple hemorrhagic bullae suspect varicella with secondary infection, and hypoalbuminemia. Diagnostic planning used examinations of CD4, HBsAg, anti $\mathrm{HCV}$, IgG CMV, IgG IgM toxoplasma (awaiting result), $\operatorname{IgG}$ varicella $\operatorname{IgM}$, culture and sensitivity from blood, urine and bullae. The patient's therapy used similar treatment with additions of 1 ampoule Antrain drip in $\mathrm{NaCl} 0.9 \% 100$ cc every 8 hours (if necessary); systolic $3 \times 500 \mathrm{mg}$; Codeine $3 \times 10 \mathrm{mg}$, Compressed NaCL $0.9 \%$ with monitoring of clinical and vital signs.

On the seventh-ninth day (September $16^{\text {th }}-18^{\text {th }}$, 2015), the patient's pain complaints were reduced. Physical examination showed stable vital signs and VAS 7. Based on the local status of regio pedis dextra et sinistra, we found vesicles with multiple hemorrhagic bullae, crusting, erosion and pus. We also found eroded and crusted vesicles in the gluteus region. The Tzanck test showed the patient was positive with giant cells. The laboratory examination found hemoglobin $8.6 \mathrm{~g} / \mathrm{dL}$, hematocrit 26.4, leucocytes 5,700, neutrophils $79 \%$, lymphocytes $10 \%$, platelets 230,000 , Erythrocyte Sedimentation Rate 47, C3 82, C4 52, HbsAg positive, anti-HCV negative, IgM IgG Toxoplasma negative, IgG Rubella negative, IgG anti-CMV 216, Albumin 2.9 $\mathrm{g} / \mathrm{dL}, \mathrm{CD} 4$ count 17 , igG HSV was negative, and igM HSV was negative. The patient's diagnosis was AIDS, candidiasis oris et vaginalis, varicella with secondary infection, hypoalbuminemia, anemia, and hepatitis B. Diagnostic planning used gram staining, the Tzanck test, awaiting result of blood culture and urine, and bullae fluid, HBV DNA, HBEA. Therapy planning added $5 \times 800 \mathrm{mg}$ acyclovir tablets orally, Sodium fusidate ointment 3-4 times daily, Salicyl talc 2 times daily, $2 \times 1$ gram Ceftriaxone IV injection, wound care using normal saline $0.9 \%$ and Daryan-tulle with monitoring of clinical and vital signs.

On the twelfth day (September $21^{\text {st }}, 2015$ ), the patient's pain complaints were reduced and no new red bumps were found. Physical examination showed stable vital signs. Local status of pedis dextra et sinistra examination found vesicles with crusted multiple bullae (cracked bullae, which had started to dry). The patient's diagnosis was AIDS, candidiasis oris et vaginalis, varicella with secondary infection, Hepatitis B, hypoalbuminemia, dyspepsia, and anemia. Diagnostic planning was not 
made. Therapy planning was stopping the Codeine $3 \times 10 \mathrm{mg}$ with monitoring of clinical and vital signs.

On the thirteenth day (September 22 $\left.{ }^{\text {nd }}, 2015\right)$, the patient's pain complaints were reduced (VAS 5). Physical examination showed stable vital signs. Local status of pedis dextra et sinistra and gluteus examination found vesicles with bullae and crusting, and some of the bullae had cracked and started to dry. The patient's diagnosis was AIDS, candidiasis oris et vaginalis, varicella with secondary infection, Hepatitis B, hypoalbuminemia, and anemia. Diagnostic planning was not made. Therapy planning was stopping sistenol $3 \times 500 \mathrm{mg}$ per oral; other therapies were maintained (injections were replaced with oral applications). The patient was discharged from the intermediate and infectious care unit room, with antibiotic therapy replaced with cefixime $2 \times 200 \mathrm{mg}$ orally; acyclovir $5 \times 800 \mathrm{mg}$ continued for 3 days, cotrimoxazole forte $1 \times 960 \mathrm{mg}$ and planned antiretroviral administration from the intermediate and infectious care unit room (monitoring 3 days after discharge) with monitoring of clinical and vital signs.

On October $13^{\text {th }}, 2015$, the patient visited the intermediate and infectious care unit room for general monitoring. The patient had less pain (VAS 3 ) and no new red bumps. Physical examination showed stable vital signs. Local status of pedis region dextra et sinistra and gluteus examination did not find any vesicles and bullae, but there was still crusting. The patient's diagnosis was AIDS, candidiasis oris et vaginalis improved, varicella with improved secondary infection, Hepatitis B, and hypoalbuminemia. Diagnostic planning included viral load testing, HBV, Deoxyribo Nucleic Acid (DNA), Albumin, and Complete blood. Therapy planning included ARV therapy with Fixed Dose Combination (FDC) lamivudine, tenofovir and efavirenz 1x1 tablet per day, 5 Nystatin drops every six hours, Sodium fusidate ointment 3-4 times daily, Salicyl talc twice daily, wound care using normal saline $0.9 \%$ and Daryan-tulle. Clinical, vital sign and kidney function monitoring was planned.

\section{DISCUSSION}

Immunocompromise comprises a decreased immune system that subsequently makes the subject prone to infection. This is caused by genetic factors, acquired, iatrogenic, or transplantation. HIV infection is an acquired immunocompromised state (Mack, 2014). According to the WHO, a positive HIV infection diagnosis is found by an antibody test (rapid or laboratory-based enzyme immunoassay), positive HIV serology, or its component (HIV-RNA or HIV-DNA or ultrasensitive HIV p24 antigen). An HIV test is advisable for risky groups (IDUs, commercial sex workers/prostitutes, MSM), people with sexually transmitted infections and their sexual partners. Clinical manifestations of suspected HIV infection include weight loss of more $10 \%$ of previous body weight, fever for more than 1 month, chronic diarrhea, widespread lymphadenopathy, skin disorder (pruritic papular eruption), recurrent fungal infections, or recurrent viral infections. Early diagnosis of HIV infection and proper management can reduce morbidity, mortality and disease transmission (Lahoti et al., 2017).

HIV patients' immune system drops in the earliest HIV stage due to specific antigen loss that presents dendritic cells. Reduced CD4 and T-helper lymphocytes (TH1 and TH2) also play an important role in the immune system. A decreased immune system causes a shift in the dominance of the immune response from Th1 to Th2. This is considered a cause of atypical skin manifestations in HIV (Dyche and Hay, 2000).

Patients are diagnosed with HIV because of weight loss, chronic diarrhea, canker sores, or candidiasis, and a 2-month fever, positive HIV rapid test, positive 3-method test and CD4 cell count $17 / \mathrm{mm}^{3}$. After being diagnosed with HIV, certain dermatological (mucocutaneous) manifestations may be used as a clustering system of HIV clinical or opportunistic infection stage (Cook GC, 2009). Clinical stages may determine progression, prognosis, or initiation of antiretroviral (ARV) therapy. HIV causes the progression of atypical skin manifestations and fails standard therapy (Kovarik, 2010). HIV-related skin disease conditions are categorized into three groups: specific for HIV infection, related to increasing prevalence of HIVinfected patients, and co-incidence with HIV positive. Skin manifestations occur twofold higher if the CD4 cell count is less than $100 / \mathrm{mm}^{3}$ (Rothenbuehler et al., 2016).

Dermatological manifestations in HIV are caused by infections (viruses, bacteria, fungi, arthropods) and noninfectious (inflammation, malignancy, drug reactions), with a prevalence of about $80-90 \%$. Mucocutaneous lesions of HIV patients based on their morphology are differentiated into morbilliform eruption, erythroderma, umbilicated papules, folliculocentric papules, blistering disease and ulcers. Differential diagnosis of blistering disease includes bullous impetigo, herpes simplex, herpes zoster, varicella, pustular psoriasis, erythema 
multiforme, Steven Johnson's syndrome, toxic epidermal necrolysis, and porphyria cutanea tarda (Kovarik, 2010).

The HIV patient's anamnesis exhibited blister complaints beginning with red bumps containing clear body fluid on the upper limb, gluteus and lower extremities. She had no history of drug usage, drug allergies, or sexually transmitted diseases. In the physical examination, local status was observed to be in the form of vesicles with multiple hemorrhagic bullae, crusting and erosion. Therefore, the patient still had a differential diagnosis between varicella, herpes zoster, herpes simplex and other viral infections.

The most common causes of viral infection in HIV are herpes simplex virus/HSV (HSV 1, HSV 2) and Varicella Zoster Virus/VZV (Zijlstra, 2014). HSV and VZV are families of herpesviridae DNA viruses that become latent and settled in the nervous system of the trigeminal and dorsal root ganglia. Clinical, cellular and molecular differences are presented in the table below (Steiner et al., 2007).

Table 1: Clinical differences between reactivated HSV and VZV infections.

\begin{tabular}{|c|c|c|}
\hline & HSV & VZV \\
\hline $\begin{array}{l}\text { Recurrence } \\
\text { during lifetime }\end{array}$ & Many times & $\begin{array}{l}\text { Usually one } \\
\text { episode }\end{array}$ \\
\hline $\begin{array}{l}\text { Recurrances in } \\
\text { relation to age }\end{array}$ & Decrease & Increase \\
\hline $\begin{array}{l}\text { Cutaneous } \\
\text { distribution }\end{array}$ & $\begin{array}{l}\text { Localized and } \\
\text { focal }\end{array}$ & $\begin{array}{l}\text { Entire } \\
\text { dermatome }\end{array}$ \\
\hline $\begin{array}{l}\text { Sensory } \\
\text { complaint and } \\
\text { deficit }\end{array}$ & None or mild & $\begin{array}{l}\text { Severe pain, } \\
\text { hypoesthesia }\end{array}$ \\
\hline $\begin{array}{l}\text { CNS } \\
\text { involvement }\end{array}$ & $\begin{array}{l}\text { Virtually none; } \\
\text { sometimes } \\
\text { meningitis with } \\
\text { HSV2 }\end{array}$ & $\begin{array}{l}\text { CSF } \\
\text { pleocytosis, } \\
\text { sometimes } \\
\text { myelitis, rarely } \\
\text { angiltis or } \\
\text { encephalitis }\end{array}$ \\
\hline $\begin{array}{l}\text { Association } \\
\text { with } \\
\text { immunosuppres } \\
\text { sion }\end{array}$ & $\begin{array}{l}\text { Usually not a } \\
\text { disorder of } \\
\text { immunocomprom } \\
\text { ised hosts }\end{array}$ & $\begin{array}{l}\text { Associated with } \\
\text { age-mediated } \\
\text { decrease in cell- } \\
\text { mediated } \\
\text { immunity and } \\
\text { under } \\
\text { immunosuppres } \\
\text { sion }\end{array}$ \\
\hline $\begin{array}{l}\text { Cellular } \\
\text { location of } \\
\text { latent viral } \\
\text { genome }\end{array}$ & $\begin{array}{l}\text { Exlusively } \\
\text { neurons }\end{array}$ & Mainly neurons \\
\hline
\end{tabular}

HSV is transmitted through mucosal or open skin surface, and it depends on the host's immunological status. HSV1 and HSV2 are transmitted by a different route, HSV 1 via orolabial, while HSV2 is through genital/sexual intercourse (Steiner et al., 2007). HIV patients have a wide and chronic (more than 1 month) manifestation of CD4 cell count and HIV clinical stage (stage 4) (Kovarik, 2010). Clinical manifestations of HSV 1 (oropharyngeal) are characterized by buccal and gingival mucosal lesions, fever, intraoral infection (primary), and lip lesions (recurrent). Lesions are preceded by pain, burning, tingling, or itching, before vesicles appear in the vermillion border of the lips that lasts up to 48 hours. Afterwards, it becomes a pustule or ulcer and forms a crust in 72-96 hours. Manifestations of HSV 2 (genital) are characterized by macular and papular lesions followed by vesicles, pustules and ulcers. Possible complications include foot paresthesia and dysesthesia, perineum, dysuria, lymphadenopathies and malaise. Normally, blister rupture occurs within 1 week with a 2 -week healing period, but the process may take longer in immunocompromised patients. HSV infection diagnosis includes clinical examination, virus-infected keratinocytes from blisters (called Tzanck stains), and viral isolation in cell culture, immunofluorescence antibody tests and PCR detection of HSV DNA. Serological diagnosis can detect previous exposure (Meylan, 2011; Kovarik, 2010)

VZV can be a primary infection (varicella/chickenpox) and secondary/relapse (shingles/herpes zoster). VZV is a virus that has an envelope, double stranded DNA, and is a member of the alphaherpesvirinae subfamily. Varicella is commonly found in children, with a prevalence of $90 \%$. Envelope virions in VZV play an important role in pathogenesis. The incubation period is about 14-15 days, and transmission through infected vesicle fluid or aerosol occurs 1-2 days before a rash. This period lasts several weeks in immunocompromised patients. VZV attaches to the host cell through specific receptors and into the cytoplasm. VZV breeds on regional lymph nodes before first subclinical viremia (for 4-6 days). The second phase of viremia occurs 14 days after infection (for 10-21 days), indicating the virus spreads in the nasopharynx and skin, and there is a maculopapular-vesicular rash. The transmission period stops when all lesions are crusted. The role of humoral and cellular immune systems against varicella-zoster virus infection is not fully understood yet (Levin et al., 2016; Heininger and Seward, 2006).

Clinical manifestations of varicella in immunocompetent patients are usually self-limited with fever, malaise, and reddish pruritic rash. 
Prodromal symptoms occur 1-2 days before the onset of a rash. The characteristic of varicella is the early emergence of a pruritic rash on the head, before spreading to the body and extremities. The erythematous macula will become a papule then a small vesicle similar to the "dewdrop on a rosepetal" image. The vesicles further become pustules and eventually form crusts and scabs within 24-48 hours. Varicella in adults is usually a widespread skin manifestation, with systemic complaints and a greater risk of complications (Grotto et al., 2008; Levin et al., 2016).

Around $25 \%$ of HIV patients have VZV infection; therefore, this can be an indicator of adult patients (especially young adults) who are at risk of HIV. If reactivation occurs, it will become herpes zoster after several months of ARV therapy (Lahoti et al., 2017). Varicella incidents in HIV patients can increase morbidity, mortality and broad atypical lesions. Possible complications include the difficulty of healing process, secondary infections, recurrent relapse and resistance to standard therapy (Levin et al., 2016). In immunocompromised patients, varicella has an atypical presentation and is difficult to distinguish from disseminated herpes zoster (as opposed to herpes zoster dermatomes). Early manifestations of varicella in HIV are usually painful due to nerve damage as a result of VZV reactivation in ganglia. Pain is primarily felt in erupted lesions. Pain varies greatly, from mild or tingling to like a piercing sharp object.

The patient had a blister skin complaint with severe pain (VAS 8-9) until the patient cried in pain. Blisters occurred within 1 week before hospitalization, preceded by vesicles and pustules from 3 weeks before hospitalization. Blisters were initially found on the body area, and left and right legs, before spreading to the buttocks and feet. Physical examination found vesicles with multiple hemorrhagic bullae, crusting and erosion. Nevertheless, it did not fit the dermatome (atypical) since it might be due to being immunocompromised (HIV). There were complications of secondary infection.

Varicella history or exposure to $\mathrm{VZV}$, rash history with a dermatomal pattern and serological testing may help VZV diagnosis. Varicella diagnosis is similar to herpes simplex, with the main difference being the reactivation of significantly higher relapse in herpes simplex. If atypical lesions or diagnosis of uncertain exanthems are necessary, swabs of lesions, tissue, skin biopsy, viral culture, direct fluorescent antigen testing, or polymerase chain reaction (PCR) are necessary. The definitive diagnosis of VZV is the isolation of virus in cell cultures that are inoculated with body fluids or the identification of VZV antigen and nucleic acids. Enzyme Linked Immunosorbent Assay (ELISA), indirect fluorescent antibody test, fluorescent antibody membrane antigen, and agglutination latex are serological tests used to distinguish VZV and other viruses. PCR lesions are the most sensitive and specific method. Histopathological and PCR examination (blood, cerebrospinal fluid, vitreous humor) may help diagnose VZV infection of visceral organs (e.g. pneumonitis, encephalitis, and retinitis). Cytological tests are less effective in the VZV diagnosis. Routine serological tests to determine VZV in HIV are not recommended (Leung et al., 2010). The Tzanck test and Tzanck smear are examinations of the ulcer friction to find Tzanck cells. This test has a low sensitivity $(60 \%)$ compared to newer techniques, and cannot distinguish between VZV and HSV. This examination is also called skin test smallpox or herpes skin test. Tzanck cells (nucleated giant cells) are found in people with herpes simplex, varicella, herpes zoster, pemphigus vulgaris and cytomegalovirus (Gershon et al., 2015).

The patient's positive Tzanck test indicated a description of giant cells. Varicella diagnosis was clinically established, but a positive Tzanck test, viral or PCR cultures were not performed due to cost limitation.

VZV patients with HIV need antiviral therapy with acyclovir, famciclovir, or valacyclovir. In addition, they need analgesics for pain management (non-steroid or narcotic anti-inflammatory). There has been no prospective, controlled study of antiviral therapy for varicella in HIV-seropositive adult patients. For non-complicated varicella, treatmenttherapy options are valacyclovir (1 gram, 3 times daily, orally) or famciclovir (500 mg, 3 times daily, orally) for 5 to 7 days. Oral acyclovir is given at a starting dose of $20 \mathrm{mg} / \mathrm{kgBW}$ to a maximum dose of $800 \mathrm{mg} 5$ times daily. Intravenous administration of acyclovir for 7 to 10 days is recommended as an initial treatment in HIV-seropositive patients with severe varicella. Therapy is changed to oral if there is no visceral involvement (Grotto et al., 2008; Wittek et al., 2010)

The patient had a noticeable improvement after being given acyclovir tablets $5 \times 800 \mathrm{mg}$ for 7 days. Therapy failure due to VZF resistance to acyclovir has been rarely reported, but it should be suspected if the patient's clinical condition does not improve within 10 days after initiation of therapy or there is an atypical skin lesion (e.g. verrucous). If this condition happens, it is necessary to check the viral 
culture. Susceptibility test of antiviral drugs for alternative therapies is conducted if there is a positive viral culture. Foscarnet can be given if there is a therapy failure (Seang et al., 2014).

The patient's clinical condition was improved after being given acyclovir; therefore, it could be inferred there was no resistance to acyclovir (therapy failure). HIV patients' seropositive lesions may become more and more severe, resulting in susceptible secondary infections and relapse despite no re-exposure. Vaccination history needs to be explored to determine the risk of transmission; therefore, it is advisable to be vaccinated to avoid VZV exposure. There may be a failure of therapy against acyclovir for HIV patients (Gershon et al., 2015). Long-term prophylaxis with antivirals to prevent varicella is not recommended. Post-exposure vaccination prophylaxis is given to HIV-susceptible patients with VZV (AIDSinfo, 2013). HIV populations without VZV infection and those at risk for measles or smallpox are given VZV immunoglobulin as prophylaxis. The VZV vaccine is provided for patients who are relatively immunocompetent. The long-term goal of long-term antiviral prophylaxis is to prevent the herpes zoster relapse in HIV-seropositive patients who have not been evaluated and do not routinely seek treatment. The attenuated viral vaccine for the prevention of herpes zoster has been FDA approved in immunocompetent patients aged $\geq 50$ years and is directly given at ages over 60 . The zoster vaccine is contraindicated in people with CD4 counts less than 200 cells/uL (AIDSinfo, 2013). In HIV-infected patients susceptible to varicella, it is advisable to have a varicella vaccination. The patient was not given zoster vaccination due to being less than 50 and a CD4 cell count of 17 .

A single episode of varicella in HIV patients is neither a sign to start antiretroviral nor an indication for delaying ARVs. Antiretroviral therapy is considered after the patient is diagnosed HIVseropositive and determines the stage. In addition, consideration should be given to prophylactic therapy (AIDSinfo, 2013). ARV is given to patients with CD4 $<350$ cells $/ \mathrm{mm}^{3}$ or HIV RNA more than 55,000 copies $/ \mathrm{ml}$ (b-deoxyribonucleic acid or reverse transcriptase polymerase chain reaction). ARV therapy can suppress viral load, improve the immune system, quality of life, and reduce morbidity and mortality (Sungkanuparph et al., 2008). Prophylactic (primary/secondary) therapy may be given with cotrimoxazole 1 x960 mg 2 weeks before antiretroviral treatment if the CD4 count < 200 cells $/ \mathrm{mm}^{3}$. ARV initiation is considered in patients who are relapsing or have complications (e.g., PORN, encephalitis) (AIDSinfo, 2013).

The patient received prophylactic treatment of cotrimoxazole 1x960 mg orally. Antiretroviral therapy was administered when she was being monitored in the intermediate and infectious care unit room with FDC regimens (Tenofovir, Lamivudine and Efavirenz) 1x1 tablet per day. It is necessary to monitor the antiviral side-effects of $\mathrm{VZV}$, but it is important to distinguish whether a complaint is an antiviral drug effect or an existing complaint. Some journals have reported immune reconstitution after starting antiretroviral therapy due to increased frequency of VZV reactivation. An observational study has shown that the risk of zoster increased twice to four times between four and 16 weeks after starting antiretroviral therapy. Therefore, management can be given in the manner described in the previous discussion (Dunic et al., 2005; Espinosa et al., 2009).

The patient started ARV therapy after discharge. There was neither clinical presentation of herpes zoster nor the presence of immune reconstitution inflammatory syndrome during the monitoring.

\section{CONCLUSIONS}

It has been reported that a 27 -year-old female patient presented with a major red bump complaint on the skin from 2 weeks. The patient arrived in a weak condition; the skin appeared to have pus-filled bullae, crusting and erosion. According to the results of physical examination and laboratory examination, the patient was diagnosed with varicella with complication of secondary infection. The patient improved during the treatment. The patient's prognosis improved, but she might later have herpes zoster risk.

\section{REFERENCES}

AIDSINFO. 2013. Guidelines for Prevention and Treatment of Opportunistic Infections in HIV-Infected Adults and Adolescents [Online]. Available: http://aidsinfo.nih.gov/guidelines [Accessed 2/22 2016].

COOK GC, M. P., ZUMLA A, 2009. Manson's tropical diseases, Dermatological problems chapter 19, 22nd edition,.

DUNIC, I., DJURKOVIC-DJAKOVIC, O., VESIC, S., ZERJAV, S. \& JEVTOVIC, D. 2005. Herpes zoster as an immune restoration disease in AIDS patients during 
therapy including protease inhibitors. Int J STD AIDS, $16,475-8$.

DYCHE, J. A. \& HAY, R. J. 2000. HIV, the skin and the impact of antiretroviral therapy. Curr Opin Infect Dis, 13, 99-101.

ESPINOSA, E., PENA-JIMENEZ, A., ORMSBY, C. E., VEGA-BARRIENTOS, R. \& REYES-TERAN, G. 2009. Later onset of herpes zoster-associated immune reconstitution inflammatory syndrome. HIV Med, 10, 454-7.

FAUCI AS, L. H. 2005. Immunodeficiency Virus Disease: AIDS and Related Disorders, USA, The McGraw-Hill Companies, lnc.

GERSHON, A. A., BREUER, J., COHEN, J. I., COHRS, R. J., GERSHON, M. D., GILDEN, D., GROSE, C., HAMBLETON, S., KENNEDY, P. G., OXMAN, M. N., SEWARD, J. F. \& YAMANISHI, K. 2015. Varicella zoster virus infection. Nat Rev Dis Primers, $1,15016$.

GROTTO, I., BALICER, R. D., SMETANA, Z., DAVIDOVITCH, N., BAR-ZEEV, Y., MENDELSON, E., ZARKA, S. \& HUERTA, M. 2008. Immunity to varicella zoster virus among young adults: a decline prior to widespread uptake of varicella vaccines. Infection, 36, 130-4.

HEININGER, U. \& SEWARD, J. F. 2006. Varicella. Lancet, 368, 1365-76.

JORDAAN 2008. Common skin and mucosal disorders in HIV/AIDS. San Antonio Family Practice,, 50, 14-23.

KOUZNETSOV, L., KUZNETSOV, A. V., RUZICKA, T., MATTERNE, U., WIENECKE, R. \& ZIPPEL, S. A. 2009. Knowledge and attitude regarding human immunodeficiency virus/acquired immunodeficiency syndrome in dermatological outpatients. J Eur Acad Dermatol Venereol, 23, 927-33.

KOVARIK, C. L., KEKITIINWA, A. AND SCHWARZWALD, H. 2010. Cutaneous manifestations of HIV infection, Houston, Baylor College of Medicine.

LAHOTI, S., RAO, K., UMADEVI, H. S. \& MISHRA, L. 2017. Correlation of mucocutaneous manifestations of HIV-infected patients in an ART center with CD4 counts. Indian J Dent Res, 28, 549-554.

LEUNG, J., HARPAZ, R., BAUGHMAN, A. L., HEATH, K., LOPAREV, V., VAZQUEZ, M., WATSON, B. M. \& SCHMID, D. S. 2010. Evaluation of laboratory methods for diagnosis of varicella. Clin Infect Dis, 51, 23-32.

LEVIN, M. J., WEINBERG, A. \& SCHMID, D. S. 2016. Herpes Simplex Virus and Varicella-Zoster Virus. Microbiol Spectr, 4.
MACK, M. A. G., K. 2014. Diagnosis and Management of Infections in Hospitalized Immunocompromised Patients. Hospital Medicine Clinics, 3, e378-e395.

MEYLAN, P. 2011. [Herpes simplex virus infections, an update for the practitioner]. Rev Med Suisse, 7, 886-8, 890-3.

NASRONUDIN 2015. Infeksi HIV, Surabaya, Airlangga university press.

ROTHENBUEHLER, S. P., OBERMANN, E. C., ITIN, P. H. \& GOLDBLUM, D. 2016. Subkutanes Granuloma anulare am Orbitarand kann eine Dermoidzyste imitieren. Klin Monbl Augenheilkd, 233, 409-10.

SEANG, S., BOUTOLLEAU, D., BURREL, S., REGNIER, S., EPELBOIN, L., VOUJON, D., VALANTIN, M. A., KATLAMA, C., AGUT, H. \& CAUMES, E. 2014. Long-term follow-up of HIVinfected patients once diagnosed with acyclovirresistant herpes simplex virus infection. Int $J$ STD AIDS, 25, 676-82.

STEINER, I., KENNEDY, P. G. \& PACHNER, A. R. 2007. The neurotropic herpes viruses: herpes simplex and varicella-zoster. Lancet Neurol, 6, 1015-28.

STERLING TR, C. R. 2005. General Clinical Manifestations of Human Immunodeficiency Virus Infection (Including the Acute Retroviral Syndrome and Oral, Cutaneous, Renal, ocular, and Cardiac Diseases), USA, Elsevier Inc.

SUNGKANUPARPH, S., ANEKTHANANON, T., HIRANSUTHIKUL, N., BOWONWATANUWONG, C., SUPPARATPINYO, K., MOOTSIKAPUN, P., CHETCHOTISAKD, P., KIERTIBURANAKUL, S., TANSUPHASWADIKUL, S., BUPPANHARUN, W., MANOSUTHI, W., TECHASATHIT, W., RATANASUWAN, W., TANTISIRIWAT, W., SUWANAGOOL, S., LEECHAWENGWONGS, M., RUXRUNGTHAM, K. \& THAI, A. S. 2008. Guidelines for antiretroviral therapy in HIV-1 infected adults and adolescents: the recommendations of the Thai AIDS Society (TAS) 2008. J Med Assoc Thai, 91, 1925-35.

WITTEK, M., DOERR, H. W. \& ALLWINN, R. 2010. [Varicella and herpes zoster. Part 2: therapy and prevention]. Med Klin (Munich), 105, 399-403.

WIWANITKIT, V. 2004. Prevalence of dermatological disorders in Thai HIV-infected patients correlated with different CD4 lymphocyte count statuses: a note on 120 cases. Int J Dermatol, 43, 265-8.

ZIJLSTRA, E. E. 2014. PKDL and other dermal lesions in HIV co-infected patients with Leishmaniasis: review of clinical presentation in relation to immune responses. PLoS Negl Trop Dis, 8, e3258. 